Gyarmathy E (2013) The Gifted and Gifted Education in Hungary. Journal for the Education of the Gifted, Volume 36 Issue 1 March 2013 pp. 19 - 43. DOI 10.1177/0162353212471587

\title{
Éva Gyarmathy The gifted and gifted education in Hungary
}

\section{Introduction}

Scene: a sauna in Budapest. A child of about seven enters and sits down, at which an ill-natured, disdainful adult makes a snide remark: "I wouldn't have thought they'd allow children here!" The kid replies: "Indeed, I've read the information on the wall outside. Children are allowed to enter, but may only sit in the bottom row so as to avoid any possible harmful effects on their health. That's why I'm sitting down here. May I turn over and start the hour-glass?" Isn't this beautiful? The child first embarrassed its partner with a level of knowledge unheard of by the latter, then steps out of the role of the child and plays a different game: he obliges the person who just a minute before had tried to humiliate him. He is a genius of communication. (Based on http://csermelyblog.tehetsegpont.hu/node/233)

Scene: a chemistry competition in Karcag, a small town. Teams of 10 to 12 year-old children are sitting at the tables and solving the tasks. There is only one child, who just cannot sit still: he sits, and then virtually lies on the table, wriggles in extraordinary positions, but all this time, would not let his eyes stray from the task they have to solve. As chairman of the judges, I say to myself: "Well, well! Let's see what will become of this!" Naturally, it was this child's team who happened to win the competition. Naturally, the contribution of that particular child happened to be highly important. (Based on http://csermelyblog.tehetsegpont.hu/node/233)

The real challenge is to see value that is not yet in its true form. Becoming gifted is a process, during which characteristics of giftedness are present throughout, but not necessarily in a form perceptible or acceptable to the environment. Giftedness does not hide itself, only to the extent that the environment believes it hidden. Perception defines the pattern that manifests itself.

Giftedness is naturally present in everyday life, but is easily pigeon-holed based on superficial criteria. If the abilities of a person are more obvious, then his/her idiosyncratic habits are more easily accepted, than in the case when abilities leading to achievements are not as clearly observable. The latter kind of gifted individual presents the real challenge.

Observation is the best aid in identifying the gifted. I suggest the following truly precise definition of giftedness for observation-based identification: a gifted individual is an individual with great knowledge and the habit of a pre-school child - which means activeness, questions, a naïve openness to the world and strong goal-orientedness.

The two children from the stories above might not qualify for the category of giftedness on a standardised method of gifted identification. Of course, this would not necessarily hinder them, save should the environment put obstacles to their unique solutions and identified their unconventional behaviour and idiosyncratic development as a disorder instead of accepting it and paving their way towards achievements. 


\section{A hundred years of gifted education in Hungary}

The beginning of the $20^{\text {th }}$ century is a success story of Hungarian gifted education. Outstanding teachers and their students have reached outstanding achievements through gifted education linked to everyday education. Their methods and ideas are durable, and are therefore worth recalling.

László Rátz (1863-1930) was a teacher of legendary fame of the Fasor Evangelical High School in Budapest. He taught some outstanding mathematicians, physicists and chemists. Excellent minds were educated under him such as Nobel Prize-winning physicist Eugene Wigner, mathematician John von Neumann (among others, founder of the field of game theory), as well as Nobel Prize-winning economist John Harsányi.

Professor Rátz is one of the great reformers of Hungarian mathematical education. In 1906, he founded the Reform Committee of Mathematics together with Manó Beke and Sándor Mikola, among others. The committee declared that there are certain aspects of mathematics, too, that are acquired unconsciously and these should be reinforced in the learner. The learning of mathematics should be full of direct experience and doing a lot of measurements. They stressed the importance of mental arithmetic and of practising estimating. The essence of their way of education, which begets Nobel laureates, is that learning requires facts built on practical experience, as well as the development and constant use of thinking abilities, on the one hand, and the development of a good sense of judgement and its utilization in the thinking process, on the other.

Elek Szitnyai (1905), a teacher at a main high school of Budapest, observed that school can provide nourishment only to a small part of the talents. "A lot of textbooks are a veritable outrage and an attack against children's intellects." Certain hidden talents are unable to manifest themselves in absence of certain highly beneficial effects. Therefore, every possible step should be taken to provide nourishment and a space for functioning to true and deserving talents. Often the greatest obstacle to this is ignorance and envy. The young literary historian Jenö Dóczy, in his 1910 book Talent and school already argued that only education by individualizing instruction can be eventually effective, which takes into consideration quantitative and qualitative differences between individual abilities.

Psychologist Géza Révész regarded it as one of the prime issues of future pedagogy and psychology to study talents from all possible aspects (Révész, 1918). In line with the spirit of his age, he regarded intelligence as the chief criterion of talent, but he also saw the problems of defining intelligence. He believed that no intelligence test entitles us to make prognostic statements on the presence and possible future development of talent. Far beyond his age, Révész regarded intuition, spontaneity and behaviour relating to things, human activities and creations more characteristic of talent than intelligence. These characteristics, however, are even less tangible than intelligence and even less possible to assess, which is why he considered observation based on previous experience with talent important beside measurement of intelligence.

László Nagy (1930), similarly to Révész, also regarded character and strength of will important criteria beside abilities, as lack of these lead to a talent being lost or never even 
developed. He considered individual treatment the best solution, because "children are not grains of wheat in a bushel..." Their differences should be taken into consideration in education and loosen "the iron clamps of uniformity". He championed the cause of taking the spontaneous interests of the child maximally into consideration in education and teaching. Beside this, he emphasized that different education and learning materials should be provided to different types of talent.

This was the approach on which Hungarian gifted education was based when it set off in the 1920's and 30'-s. The so called talent exam - which primarily had its roots in the city of Sárospatak in the north-eastern part of Hungary - favoured ability and the greatness and flexibility of the mind rather than ready knowledge. The most characteristic institution of the second phase of the gifted protection movement was the boarding school system in Sárospatak. Lodgers of these attic rooms were of the most excellent students of the city. This is one of the prototypical systems in Hungary for talent-based selection. All students, whether talented or not, learned together, while the talented ones also lived together. This way, they were aware of the value of their abilities, but also of the possibility of reaching an even higher level (Harsányi, 1994). Their way of life made it possible to educate each other. The teachers didn't need to press these youths to learn. The success of the Sárospatak method brought about the foundation of similar institutions, which were supported by both the Reformed Church and the state. A significant amount of state money was set aside in 1941 for saving talents this way.

These were, however, the last days of gifted education based on the Sárospatak boarding school model, and, in fact, of Hungarian gifted education itself. By raising the school leaving age to 16 years in 1948, the state considered support for the gifted solved (Harsányi, 1994). Up until the 1980 's, Hungarian gifted education took on an underground character. Gifted education was carried out in specialized classes and secretly elite high schools, and was always present in everyday education primarily as a result of the effort of some excellent teachers. Officially, however, it didn't exist during this period, since individualization did not fit in with the received political view.

The newly evolving gifted education has to find the best options for developing a background for the gifted during the value crisis that arose at the start of the third millennium. After a long period of forbidden differentiation and elitism, it is difficult to find a balance between gifted education within everyday teaching and a special provision for the gifted as a developmental environment for the already manifest talent.

\section{The current approach to giftedness in Hungary}

\section{The conception of giftedness and the development of the gifted}

In Hungarian gifted education, two approaches have been and are present simultaneously: the approach - that is often accused of elitism - which favours separate provision for the gifted, and the approach which aims to reform education and which promotes the inclusion of the support for the gifted in the process of education through attention to the individual. 
The view of giftedness currently still prominent in Hungary is the ideal of the $20^{\text {th }}$ century, that is, the school talent, who learns its lessons and is good at testing. A great part of the population identified as gifted comes from middle class students (Hatvani, 2011) who perform well in competitions. Children from a favourable family background are at an advantage, since selection is in most cases not preceded by wide-scale gifted education, which would increase the manifestation chances of gifted children with no effective background for development. Selection often begins as early as pre-school age, although gifted children are typically chosen for gifted education classes at the age of about ten years. One of the most prominent form of this approach is the "Debrecen Paradigm" (Pappné Gyulai, \& Pakurárné, 2011).

The easy way to take in gifted education is to select ready-made gifted children, but this comes at the price of a vast amount of "reject production". Pursuing fast achievements results in the loss of many a real talent and makes the evolution of true gifted education difficult. Révész (1918) maintained that the greatest enemies of talent are the untalented, who are numerous and try to protect themselves. The pits of Hungarian gifted education are the manifestation of just this problem.

The official Hungarian concept of giftedness is based on the approach of the Renzulli model (1978), and describes giftedness in the interaction of some important groups of properties:

- above average general abilities,

- above average special abilities,

- creativity,

- commitment to the task and motivation.

The National Council of Support for the Gifted accepted the following simplified definition in 2007: "Thus, individuals can be regarded as gifted if their excellent abilities - as a combination of the above four components - enable them to be capable of a high-level achievement in some area of life." (Balogh, \& Mező (Eds.), 2010)

The Hungarian approach to giftedness, however, is captured in a more colourful way by Czeizel's (1997) multidimensional, $4 * 2+1$ factor model of giftedness, which reflects the interaction of abilities and external environmental effects. The four-ring figure illustrates the interaction of genetic traits (hereditariness) and environmental effects. Giftedness is seen to be rooted in four genetic factors - general mental abilities, specific mental abilities, creative abilities and motivational abilities - and four environmental factors - family, school, peer groups and the general social environment. Each environmental factor can be either positive or negative, and thus form a complex compound. This all is supplemented with the unpredictable "factor of fate" (see Figure 1).

An additional factor according to Czeizel is that it is necessary to reach an age suitable for creation, that is, a certain lifespan is necessary. He describes the most extreme form of talent loss in relation to life health. In view of the increasing mortality in Hungary (Kopp, \& Skrabski, 2009), this issue may be of considerable significance. 
Figure 1 The four ring model of Czeizel

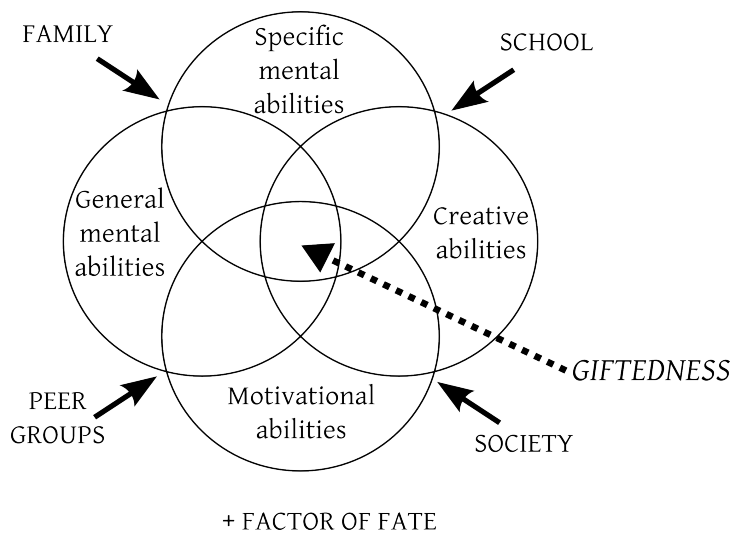

The Hungarian language is restricted in its ability to discriminate between different forms of giftedness. Czeizel (1997) suggested, basically in line with the model of Gagné (1991), the use of giftedness ("tehetség") to describe an individual with significantly above-average, that is, exceptional abilities, potential or promise. Potential and a fulfilled promise should be differentiated. He suggested the use of the term talent ("talentum") - already employed by Révész (1918) - in the case of individuals who display giftedness in creation. This concept, however, did not make it into either the professional terminology, or popular knowledge.

The officially accepted concept of giftedness also fails to make such distinctions. As a consequence, discussions of professional issues often stray into territories of vagueness. In addition, the gifted education that started in the 1980's is built on the psychometric approach of the $\mathbf{2 0}^{\text {th }}$ century (Vass, Dobó, Nahalka, Ollé, Perjé, \& Virányi, 2011), and can only slowly turn into a $21^{\text {st }}$ century type of Hungarian gifted education.

A reason for this is that in the now classical description of gifted education, three basic stages are desirable, denoted as the three "D's" in the literature (Solano, 1979; Rosemarin, 1999): Description, Discovery and Development, which less wittily, but more precisely put, covers the following three basic issues relating to giftedness:

1. Defining giftedness

2. Identifying giftedness

3. Developing giftedness

These three stages are all an important part of dealing with the gifted, but in the $21^{\text {st }}$ century, when a change in culture and the tools of the digital age seem to be altering the thinking of children and the needs of society to an unprecedented degree, efficient gifted education appears to require exactly the opposite order. If we want society and human culture to be able to have a pick from as diverse talents as possible, then as diverse kinds of talent should be given the opportunity to manifest themselves as possible. To this end, gifted education should be included into everyday education and beyond that, into everyday culture, and too early restriction of the circle of talents through selection by identification should be avoided. 
The most efficient identification of giftedness is the development of giftedness. If opportunity is given to the gifted, then their identification becomes virtually automatic through their manifestation. In this approach, the very last step is the definition of giftedness, that is, determining what kind of talents the given period needs. The gifted education of the future therefore is as follows:

1. Developing giftedness

2. Identifying giftedness

3. Defining giftedness

The conception of giftedness has definitely begun to change in professional circles. Table 1 offers an overview of the elements of this change. Professionals increasingly rely on observational data instead of a rigid psychometric approach. Assessments increasingly tend to focus on understanding giftedness rather than identifying it. Even practical gifted education is being permeated with the idea that manifestation of talent needs a suitable environment, whereby an individual wishing to achieve more than others in a given area and willing to exert extra effort to this end is more likely to manifest itself.

Table 1 Changes in the conception of giftedness in the last decade (from Gyarmathy, 2007)

\begin{tabular}{|l|l|}
\hline \multicolumn{1}{|c|}{ Earlier } & \multicolumn{1}{c|}{ Today } \\
\hline giftedness = ability & giftedness = complex system of behaviour \\
\hline a child is gifted & giftedness based on achievement \\
\hline identification of giftedness & discovering strengths and weaknesses \\
\hline terminal selection & continuing, long-term monitoring \\
\hline general giftedness & specific area \\
\hline objective data & combined with subjective data \\
\hline tests used in identification & identification based on gifted education \\
\hline
\end{tabular}

\section{Misconceptions which burden gifted education}

A popular view is that "everyone is gifted". This is probably a new manifestation of the old equalism: in the communist era of the country, no one could be worth more than others. In the democracy today, everyone "deserves" giftedness. In folk psychology, the Hungarian term for "ability", like aptitude, is in the singular number, and designates general intelligence, which is why its meaning is easily identified by many with the concept of giftedness (Vass, Dobó, Nahalka, Ollé, Perjé, \& Virányi, 2011). The synonymous use of the terms "good ability" and "giftedness" in popular speech acknowledges giftedness confined to abilities, and thus the idea that "everyone has some good abilities" easily leads to the idea that "everyone is gifted".

Many are aware of the falseness of this view, however. If everyone is talented, then the concept itself becomes spurious, and fails the Sternbergian criteria of rarity. Sternberg (1993) set up criteria for giftedness in a pentagonal model, according to which giftedness is 
manifest in a rare, outstanding, demonstrable and value-producing achievement (see Figure 2).

Figure 2 Sternberg's (1993) pentagonal model

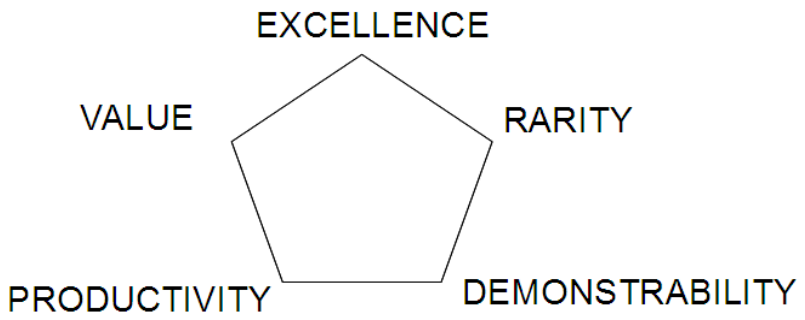

Everyone can be excellent and have outstanding abilities or achievements. If, for instance, children were educated according to the method described by László Polgár (2008), father of the outstandingly successful chess-player Polgár girls, they would be capable of cognitive achievements far above their current abilities. Until this method becomes general, individuals whom their environment has given more opportunity to develop their abilities will appear to be gifted. Naturally, some may be extraordinary talents, but individuals whom we could call an "average talent", whose achievements are attainable to many given the right environmental background, also make it to the group of gifted.

A much more sustainable and useful approach is "to regard everyone as a potential talent". This approach is in Hungary primarily held by the Council for the Support of the Gifted with Special Education Needs and its members, but more and more people begin to see the advantages of the approach.

This approach is highly important for the reason that it promotes a more differentiated view of giftedness. A wide-spread notion is the "everything or nothing" motto, according to which every talent is talented in all areas. People tend to think that whoever is an excellent computer engineer or poet, then his or her financial advice should also be heeded, or alternatively, whoever is incapable of reading well, must be incapable of outstanding achievements in all other cognitive areas, as well.

Average or even below average knowledge in some areas, however, does not negate or undo the individual's outstanding areas. Consequently, profiling tests are gaining ground in the assessments of giftedness (Gyarmathy, 2010).

A further burden on the gifted is the motto "Palma sub ponder crescit", that is, "a palm grows under pressure", which does substantial harm in gifted education. Overexertion increases anxiety and achievements will often be missing. Too early achievement can undermine later outstanding creative work.

A twin brother of this view is the slogan "talent cannot be subdued", according to which whoever fails to become a talent is in fact no talent. The great Hungarian poet Sándor Petőfi wrote in a letter, "No talent is lost in this world. Nature is no fool to create strengths in vain. What it creates, it creates to have use thereof" (February 1847). But then gifted education would be a superfluous activity. It is possible for an individual to possess an internal drive 
that would not let its talent rest still and would make it evolve even under the most unfavourable circumstances. This is, however, hardly something on which to base support for the gifted.

Turning potential into ability and then growing it into achievement requires enduring effort, which in turn requires a supportive environment. Outstanding abilities can sometimes also be an obstacle to outstanding achievements, because they lead to easy successes. Many gifted individuals with outstanding abilities are lost by choosing the easier way, and waiting for achievements to show up by themselves. Popular thinking often regards diligence as a compensation for weak abilities and does not acknowledge it very much.

Finally, an unfortunately frequent mistake, though rarely explicitly voiced, is zero sum thinking. In essence, people tend to believe that if someone has more of something, this automatically means that someone else has less of it. This can generate a grudge against the gifted, though the gifted in fact open up opportunities for everyone without taking from anyone.

\section{Legislative aspects of gifted education in Hungary}

While the new education act stresses the importance of gifted education in several places, in practice it fails to provide real opportunities for it. Hungarian education management basically runs counter to the ideas of professionals in gifted education. The new educational reform confines education to a more rigid framework than before. The strict confines imposed by the central curriculum does not only fail to take into consideration the diverse forms of talents, but also the diversity of the not so outstanding individuals.

The legislation regards children who need special treatment as falling into at least one of the following groups:

1. A child or student has special education needs if he or she was diagnosed by the relevant expert committee for some motor, sensory, mental, speech or multiple disability, autism spectrum disorder or other psychological developmental disorder (such as learning, attention, behaviour or impulse control disorder).

2. A child has integration, learning or behaviour difficulties if he or she has specific problems whose level is not as serious in the above categories, but whose simultaneous presence results in significant underachievement, social relation problems or deficits of behaviour control in comparison to the child's age and school grade.

3. A child is talented if he or she possesses above average general or specific abilities and a high level of creativity, and a strong motivation and commitment to the task can be aroused in him or her.

Participation in special education and boarding school provision, including participation in first basic education in music and arts, is free of charge in all cases for each child with specific education needs or integration, learning or behaviour difficulties (National Public Education Act, 2012). To gifted children, in contrast to the other two groups of children with 
special treatment needs, no support is made available beside listing them as requiring special treatment. Therefore, a gifted child can only receive the above-mentioned support if he or she has diagnosed integration problems at the least.

Gifted education is a designated activity in the public education act, whose framework is provided by the National Talent Programme and which is subsidised by the National Talent Fund. The government designated the following as high priority areas in the two-year action programme for 2011-2012 to execute the objectives set out in the National Talent Programme:

a) to sustain and enrich traditions of support for the gifted,

b) ensuring equal access in the area of support for the gifted and promoting value-based social mobility,

c) to increase the community-forming and social responsibility of talented youths,

d) valuing individuals and organisations (educational institutions) that take part in supporting the gifted,

e) advancing the development of a talent-conscious (systems helping spread programmes and best practices that target equal opportunities) and talent-friendly society (local governments, ethnic minority governments, councils for the support of the gifted),

f) assisting the collaboration of Hungarian gifted support communities in Hungary and in neighbouring countries,

g) valorising the results of Hungarian gifted support in other member states of the European Union and other states.

The minister assists gifted education through supporting national gifted education collaboration, professional recommendations, as well as calls for project proposals and contest notices (Public Education Act 2012).

Such grants for possible episodic activities described by the legislation bring about ad hoc types of gifted education programmes. There is no continuous, ongoing funding of supporting and working with the gifted either inside or outside regular education. When a project culminates, the work is done and it is uncertain whether and how it can continue.

A further problem is that gifted education is relegated as a task to public education institutions. Six and eight year high schools and special colleges are designated institutions for gifted education, and it is their duty to unfold students' abilities and potential, to identify, register and individually monitor gifted learners and to support and develop the gifted, exploiting institutional and extra-institution collaboration opportunities. The legislation allocates gifted education to the obligatory tasks of teachers, which is controlled, assisted and monitored in each institution by a qualified gifted and talented coordinator teacher.

A great problem is that teachers are not suitably trained professionally: a great part of them is not even past the everyday level of understanding the concept of giftedness (Vass, Dobó, Nahalka, Ollé, Perjé, \& Virányi, 2011).

A further unsolved issue in gifted education is involving in gifted education the increasingly greater social classes that tend to fall behind. There is a specific gifted education programme for socio-culturally disadvantaged talents, the Arany János Programme, targeting the gifted education of disadvantaged high school students. 
Unfortunately, however, the effectiveness of talent saving starting in the teens is quite low. Disadvantage turns into considerable deficit by this age.

Studies show that application rates into this programme are low, which is in part due to the fact that disadvantaged children tend to lose their learning motivation already at primary school. The participation rates of Roma children are particularly low in this talent programme. The average academic record of classes consisting of disadvantaged children is lower than that of other high school classes already at the outset, and this difference tends to persist until the end of high school. Nonetheless, disadvantaged students do profit from being accepted to high school (Fehérvári, \& Liskó, 2006). Disadvantaged children accepted into elite high schools, however, are under great pressure. Many of them feel anxiety over wanting to live up to high expectations, over missing knowledge or skills and over the cultural change.

To solve these problems, the National Talent Council extends the provision of socioculturally disadvantaged talents to all ages in its Talent Bridges programme starting in 2012. Setting off pre-school gifted education programmes is also planned to increase the chances of disadvantaged children to develop their talent by preventing them from falling behind. An academically sound, but practical book "Advantage in disadvantage" was published within the framework of the Genius Project, which reviews the various areas related to and solution options for the provision of support for the socio-culturally disadvantaged gifted in Hungary.

\section{Research on gifted education in Hungary}

\section{Important contributions to gifted education in Hungary}

\section{Networks}

Péter Csermely, a biochemist researching networks, has suggested basing gifted education on networks, drawing from his research results, according to which network-based organisations work much more efficiently than the simple sum of its members, irrespective of whether these are cellular networks or the internet. On Csermely's initiative, a national programme was started to support the gifted in which so called talent points play an important role. The organisational principle thereof is the network-based approach: the system is characterised not by a single centred uniform relational form, but is formed by local, professional and skill-based relations. The collaboration and informational link between organisations and professionals working in gifted education can efficiently represent the case of talents at professional and education policy platforms, and even in front of economical decision-makers.

In gifted education, as everywhere else, lack of resources leads to crises. Csermely and his colleagues have found during their research that each bridging link increases the chances of collaborations which make it possible to take a stand and - jointly - contend for new resources instead of taking part in the desperate fight for the redistribution of the old, and owing to the economical crisis, reducing resources. 
An especially important element of building bridges is providing for the most talented, where in most cases, talent will need a brand new environment and network of relations for its optimal development. Gifted education itself is a process that constitutes a network, good examples of which are the talent points, which provide or recommend an appropriate environment for the gifted (Csermely, 2008; Csermely, Kovác, Mihalik, Nanasi, Rak, \& Szalay, 2009).

The Hungarian model is unique in that it initiates the process of strengthening giftedness support through networking.

Each node, that is, each talent point in the network does gifted education work, mostly with the help of qualified professionals. They undertake to assign not only teachers, but also psychologists, if necessary, to working with the gifted, and in addition, they also keep in contact with the family. One of the most important components of the work, however, is cooperation with other talent points, exchanging information, and willingness to get to know or transfer best practices in gifted education.

Talent points have been established all over Hungary, and even in some neighbouring countries. These can be found in the form of a talent map on the Internet (www.geniuszportal.hu/tehetsegterkep). By also involving regions across the board, several institutions and civil organisations in Hungarian communities in neighbouring countries have also founded talent points.

Two thirds of the talent points are public education institutions, kindergartens, or primary or secondary schools, but local government and church institutions have also founded talent points. In many places, gifted education is realized as the cooperation of several sectors.

Talent points are not restricted in terms of organisational character or functioning. The goal is to involve every talent-supporting organisation of a high professional level in the work of the network and make it a registered talent point. Programmes offered by the institutions are extremely diverse and many of them are of an exceptionally high level. Importantly, talent points are required to have a worked-out and professionally sound programme and methods of gifted education, and should be able to record it and share it with others to promote the spreading of best practices. Best practices of gifted education are constantly collected and published on the Internet (http://geniuszportal.hu/content/best-practices).

Organisations also benefit financially by becoming registered talent points, as they may more easily apply for grants at the National Talent Fund for talent support activities. In addition, institutions with more background experience, who have accumulated information and established relationships through the network, are able to exploit the resources more efficiently.

\section{Pre-school gifted education}

The most innovative progress in Hungarian gifted education happens in pre-school provision. Kindergarten teachers are fare more active and creative in their solutions then teachers in any other area of education. Numerous art and science programmes and projects 
are ongoing at kindergartens. A separate council for gifted support has been set up for gifted education at the kindergarten level, and under the name "Antanténusz" (from a popular children's nonsense verse), for playful thinking development at early childhood. In addition, kindergarten teachers stand out with outstanding innovations in this area.

\section{Magic box}

One of the outstanding innovations is the work of Edina Nagy (2011), a student at a kindergarten teacher college programme, who also studies at a fine arts college. She owns a company, which pursues diverse fine art activities. She herself is also youth of outstanding talent and has devised a modular game which is a method for gifted development and gifted identification in one, and may form the basis of further innumerable novel solutions. It is not only helpful in childhood, but can be utilized at all ages.

It is a tool for remedial catching up and for supporting the gifted in one. The Magic box, a patented invention, has won several awards. The modules are made of natural and white cardboard in environmentally conscious spirit. The pieces can be easily assembled and taken apart, or even "turned inside out".

Characteristics of the modular game:

- Complexity, development of multiple areas

- Opportunities for realizing custom, individual ideas

- Suitable for all ages

- Individual and group activities

- Can be developed further

- Offers 3D space

- Economical production

- EU-conform

Beside the basic package, modules with different types of surface have also been made. There are pieces with impregnated surface, which can be cleaned with water and thereby present an opportunity for renewed creation using the same pieces. There are also pieces whose outer part is covered with magnetic foil, thereby offering immense opportunities for experimentation.

The modules can be used to create strategic games, rhythm games or even musical scales of different sizes. They can be filled with different kinds of material, they can be coloured, or adorned with figures or linguistic materials.

The magic box can be used in the development of all major areas of abilities. It uncovers areas of interest and can be used to identified these:

- Linguistic

- Logical-mathematical

- Spatial-visual

- Kinaesthetic

- Music 
- Interpersonal

- Intrapersonal

It is suitable for the development of all cognitive areas:

- Sense

- Perception

- Attention

- Memory

- Thinking

- Imagination

\section{The directions of research of the past decade}

Csapó, Gajić, \& Ivanović (2011) identified four major areas in the scientific research on giftedness that have began to receive greater emphasis lately:

1. a new approach to creativity;

2. atypical brain and giftedness;

3. a change in the focus of gifted assessments;

4. issues of the challenge of the digital age.

\section{A new approach to creativity}

An important change in the study of creativity is that researchers take the social aspect of creativity into account, as well, rather than exclusively its psychological characteristics. Today's studies not only examine divergent thinking and diversity in itself, but complement this by linking it to the amount of work done. External acceptance from the society, and the personality of the maestros and mentors aiding the creative work are of particular importance in the creative activities of the creative person as a "chosen" individual. In essence, the change in today's research on creativity is manifest in a different interpretation of the relation between the individual and the society (Pléh, 2010).

Increasingly more data are processed on so called "talent maps". The distribution of talents is non-uniform. Some areas are under- or over-represented in terms of manifestation of talent (Pléh, 2010).

Models have shed light on and quantified phenomena on which concrete data had been lacking or had been sparse. It has been proven that it is possible to model areal nonuniformity just as well as any other socio-cultural phenomenon. Areas differ in terms of their talent production, talent retention and talent attraction (see the study on the talent attraction potential of Hungarian counties between 1867-1990 by Győri, 2011). 
Further - geographical, historical or professional - refinement of the patterns used for the design of the model may uncover more specific connections.

Another issue related to the social embeddedness of creativity is the identification of different types of creativity. Creativity as exceptional creativity in a specific area rather than general creativity bears a different significance in relation to the development of giftedness. While everyday creativity can be the result of general openness, outstanding professional creativity is specific to a given subject. Exceptional creativity presupposes exceptional knowledge. An immense amount of practice is necessary to exploit talent. School age is the period when it is perhaps easiest to devote ten thousand hours of one's time that is necessary for future achievement in an area, possibly only twenty years later (Pléh, 2010).

\section{Atypical brain and giftedness}

Gifted population is by far not homogeneous in terms of creative functioning. The "big C", that is, an exceptional creativity behind exceptional achievements is often rooted in an uncommon way of information processing. According to Gyarmathy (2009), special attitudes characteristic of giftedness appear virtually as a rule in the case of outstanding talents as the result of an out of ordinary brain structure. A more random creative talent, as opposed to a more regular talent, might thus be more typically rooted in specific learning difficulties, hyperactivity and attention disorder, or even Asperger syndrome.

Giftedness is a special kind of perception, attitude and reaction. Intense and obsessed activity and persevering practice are necessary for outstanding achievements, and are highly different from normal cognitive processes, which leads to a behaviour highly different from normal. A lot of the gifted show uncommon cognitive structures, non-uniform structure of abilities, right brain dominance, language difficulties or autoimmune diseases, which are often a sign of dyslexia and other specific learning difficulties to professionals.

In many cases, specific aspects of the personality of a gifted person, such as weakness in social abilities and an unbelievable level of motivation may be identified as compulsive or autistic behaviour. Abnormally high levels of activity are often diagnosed as hyperactivity disorder. The signs of giftedness capable of outstanding achievements and the symptoms of attention disorder/hyperactivity correspond in many respects. For instance, both are characterised by quick reaction, Dabrowski's over-excitabilities (Dabrowski, \& Piechowski, 1977), uncommon perception, above-average level of activity, desire for creation, curiosity, a predisposition to question authority, indefatiguability, troublesome behaviour in absence of a suitable challenge, low tolerance for monotony (Gyarmathy, 2009).

Outstanding talent may probably not only arise as a result of irregular, atypical brain development, but, contrary to earlier theories, a genius appears to be a special neurological type rather than simply a high level of giftedness. Difference is, therefore, qualitative rather than merely quantitative. One of the great challenges of the third millennium is the increasing number of children with outstanding abilities incapable of integration. The 
provision of these children and the channelling of their potential requires a change in the conception of giftedness and gifted education.

A vital condition of outstanding achievements is that the atypical gifted individual be able to live up to its abilities and more or less integrate into society. This would in turn require less rigid diagnostic approaches.

\section{A change in the focus of gifted assessments}

The 20th century giftedness ideal is a gifted individual who is capable of fitting in, who is in possession of outstanding abilities that are identifiable with tests and who is characterised by creativity. Giftedness, however, cannot be measured. More and more data affirm that even the most thoroughly designed procedures will fail in the case of individuals with special brain structures, that is, the exceptions, a special minority, of whom there are more and more, and of whom many may be capable of outstanding achievements.

One of the most important pitfalls of gifted identification is creativity. Creative power means by essence unidentifiability. Surpassing earlier existent instances is what makes something creative. Creative individuals most often manifest themselves as difficulties. An unbalanced profile of abilities and singular personality characteristic of exceptional talents renders the traditional assessment methods unreliable and unsuitable for identifying talents (Gyarmathy, 2009).

To detect incongruousness at a high level, the individual requires knowledge. Creativity is linked to abilities and knowledge. The link of creative thinking to knowledge is the reason tests of creativity tend to correlate more with intelligence tests than with each other. There are innumerable assessment tools of creativity, but despite all appearances, the assessment of creativity is unsolved. The applied procedures target the assessment of the "little-C", or everyday creativity, but even for this, results are unreliable. The circumstances under which a test is recorded significantly influence the results of assessment methods. This factor has an increased effect in the case of creativity assessment.

Creativity is less effective in a tense environment. "When guns talk the muses fall silent." Testing, however, is like a war with guns, which generates tension: it is an assessment, expectation of achievement and a timed pressure that kills creativity. This applies to testing situations and school situations alike (Gyarmathy, 2011).

Similarly to school talent identification, a serious issue with intelligence tests is that they primarily identify school- or, lesson learner talents, who can also be called testing talents. Creative productive talent, on the other hand, is more difficult to identify. During an intelligence test, it can be observed that some children do not approach the tasks in the usual rational way, because it is their imagination that leads them and makes them find original solutions. Individual testing makes it possible to detect these phenomena, while in the case of group intelligence assessments and identification tests, the "over"-creative individuals with a restless mind are disadvantaged owing to their special way of perception and interpretations (Gyarmathy, 2011). 
Studies show that of children accepted into gifted education programmes the ones who show truly substantial development are those who were selected because of their keen interest. Interest-based gifted identification is especially important in the case of talents who happen to be disadvantaged for some reason. For them, their environment has failed to provide an opportunity for harmonic development, and are thus often underachievers. Their abilities do not reflect their true potentials in most cases, but their internal drive may be manifest in the strength and direction of their interests (Gyarmathy, 2010).

The Map of Interest method (Gyarmathy, \& Herskovits, 1999) is particularly ideal in the assessment of the disadvantaged gifted, but is also highly informative in general. The method is based on the multiple intelligences model of Gardner (1983), who distinguishes seven separate intelligences in his theory, which cover the major areas of ability: linguistic, logical-mathematical, spatial, bodily-kinaesthetic, musical, interpersonal and intrapersonal. The series of statements for the map were based on the questions assembled by Armstrong (1994) for Gardner's intelligence areas. Two series of statements are used: one series is for the children to be filled in, the other is for their parents and teachers to describe the children's interests. The two series consists of the same items and both are used to discover the interests of the individual, but the viewpoint, the judging person is different (Gyarmathy, 2010).

The results can be used to determine the strengths of the individual where talent may manifest itself. At the same time, weaknesses can also be identified. Methods of development can be suggested to compensate for the weaknesses and for the use of strengths. The following are to be considered in the interpretation of the results:

1. what and how strong are the preferred areas of interest,

2. which are the areas of rejection,

3. how much inconsistency is there in the choices.

The results of the assessment can be used not only in determining the directions of development, but also in providing council. Differences between different stakeholder parties can be discussed and the different views reconciled.

\section{Challenges of the digital age}

A narrow background in terms of stimuli is less conducive to an early development of individual dispositions. Children's development used to be much more uniform in cultures less rich in stimuli, even in the $20^{\text {th }}$ century. Children formed more homogeneous groups by the time they entered school.

The developmental background for children in the digital age, however, is an environment immensely rich in stimuli. The development of children is much more heterogeneous compared to earlier times. Children's nervous system today can receive sufficient stimuli for its individual development whether it is open to verbality, whether it has a stronger need for spatial-visual development, or some areas of auditive processing are the strongest, and which, given the right stimuli, can develop into outstanding ability. Satisfying stimulus 
hunger also means that other areas might not develop uniformly when the child's stimulus hunger is restricted to some narrow area. Specialized areas of interest and activity, and due to deficits - specific learning difficulties, as well, can develop at a very early age. Studies reveal that today's children have a structure of abilities that shows a much more diffuse pattern (Gyarmathy, 2012).

School education has failed to adapt to these changes. Teachers are increasingly at a loss to treat children with a vast amount of knowledge that mostly fails to form a coherent system. School is unable to prepare them for methodical reception, processing, selection and filtering of information.

Gifted children are characterised by a greater than average stimulus hunger. They have greater opportunities for acquisition of knowledge and autonomous learning in the informational society. Gifted education, just like everyday education, should take the significant changes in culture into consideration and adapt its methodology accordingly.

\section{The future of gifted education in Hungary}

The professional basis of gifted education needs to progress in Hungary, so that it may contribute to an enhanced efficiency in research and gifted education programmes alike. The following discussion is based on Gyarmathy $(2012 a, b, c)$.

\section{Conception of giftedness}

Giftedness is a combination of outstanding abilities, which may become a creative force in an environment suitable for its manifestation. Giftedness can help an individual fulfil itself, being a way to the individual's personal and social productivity. Thus, giftedness is an element of the psychological health of both the individual and the society.

Giftedness is not an unchanging personality trait, but a group of factors for outstanding achievement that is formed in a dynamic interaction of multiple intrapersonal and environmental factors. Environmental factors, especially expectations significantly influence the manifestation of talent. Giftedness is rare, but probably not as rare as it currently appears. Everyone should be regarded and treated as a potential talent.

The later the selection, and the earlier the start of the development programme, the more talents evolve and the richer the opportunities at the disposal of the society.

\section{Gifted assessments}

The goal of gifted assessments is to ensure the appropriate developmental environment (mentors, procedures and tools, suggestion and development of possible individual/group gifted education programmes), either for an individual or for a community. Therefore, an assessment should always culminate with drawing up a development plan. The assessment should make use of multiple sources, and information should be analysed as an interaction of personal and environmental factors. 
Gifted assessments should pay equal attention to the identification of both strengths and weaknesses. Ability-, learning- and motivation profiles are necessary to design a developmental environment, and to have grounds to send the gifted children to programmes or to a mentor. Even so, even the most carefully designed assessment only represents the current situation.

\section{Gifted education and provision for the gifted}

Gifted education should extend to all individuals. Segregating the gifted can lead to talent loss. In case of segregated gifted education special attention should be paid to deal with the unnatural situation caused by the separation. Talents should be kept as much as possible in a natural environment and additional enrichment programmes should ideally complement this. Gifted assessment is only necessary when some talent programmes are starting or information is needed for some decision or development plan concerning the gifted. Observation and detection of strengths, weaknesses and interests, on the other hand, is essential from early childhood on in the case of all children.

Underachievers and irregular gifted individuals should be paid special attention in all forms of gifted education. Populations with some form of disadvantage, special education need and/or integration difficulties are at least as involved in terms of giftedness as any other groups.

High-level cultivation of a specific scientific, artistic, sports or other activity is important for everyone and offers an opportunity for the manifestation of talents in given areas. Specialization is only expected from adolescence and later, but an early start in a given area constitutes a great advantage for creative talent, and what is more, there are areas in which this is specifically necessary for the early development of abilities. However, a talent may not be restricted to a single area. It is important not to force the gifted to make a decision or choice and to give them an opportunity to develop in multiple areas of giftedness. Gifted education carried out in different areas leads to developmental processes that mutually strengthen each other.

Major forms of gifted education would include: development built into everyday activities; pronounced cultivation of a specific scientific, artistic or sport activity; gifted assessment; individual and group consultation with the family, professionals and the gifted; mentor system; tenders for project proposals; contests, performances and other appearances; vocational counselling, career building; conflict management; therapeutic treatment.

A Individual and group consultation with the family, professionals and the gifted is a continuous support in development. Gifted education is team work, and as such, the professionals should consult each other regularly.

A One of the oldest and most efficient forms of gifted education is the mentor system. A gifted individual can receive support from a dedicated mentor throughout his or her life, who can open up roads in the development of the gifted. The role of the mentor system is to help matching up mentor and mentoree.

A Creative achievements should start to come to the foreground from adolescence. Regular opportunities to participate in contests, performances and other appearances provide an opportunity to gain experience.

A Vocational counselling and career development constitute an important background for young and adult talents. 
The specialness of talents may lead to a lot of difficulties. Therefore, therapeutic provision competent in provision for the gifted should be available during gifted education.

\section{Talent-friendly society}

A talent-friendly society is primarily manifest in its general approach, as well as more specifically in its educational institutions, sustenance of a gifted education system and its recognition of outstanding achievements. A talent-friendly society regards all people as equal, but not uniform. Acceptance of the different attitude characterising the gifted helps the gifted in accepting the majority's way of thinking that is different from theirs, whereby their integration into society and the exploitation of their achievements becomes easier.

Outstanding abilities and achievements are built on the individual's belief in itself and the efficiency of its work. Development of a talent requires persistent and intensive preparation, which demands a substantial sacrifice from both the individual and its environment.

Substantial gain is to be attained through substantial investment. A return, however, might not be instantaneous; to the contrary, the return on the effort made on talent is most of the time long-term.

A talent-friendly society reinforces absorbed activity and perfectionism by leaving time for playing, learning and creation.

It ensures flexible, and at the same time predictable and strict rules and a degree of freedom appropriate for the development of abilities and the individual.

It enhances the individual's responsibility for its own actions, development and performance.

\section{Gifted assessment and provision for the talents with dual speciality (double exceptionality) - that is, with special education needs or integration and learning difficulties:}

Talents with special education needs or integration and learning difficulties are more vulnerable because of their dual speciality than individuals belonging to just one group. An unbalanced structure of abilities and an uneven development may result in a lot of failure. Individuals with a dual speciality, therefore, often fall into the group of underachieving talents. Dual speciality, at the same time, has a number of advantages. As talents, they are usually highly innovative, outstandingly creative and can draw upon more resources to compensate for their weaknesses than their peers with no giftedness.

In assessments of individuals with a dual speciality, attention should be paid to the distorting effects of adaptive (that is, conducive to development, coping and integration) and maladaptive (that is, hindering development, coping and integration) methods adopted by the individual. In the case of individuals with a dual speciality, only profile assessments are able to reflect an at least marginally reliable image of the individual, and assessment of interests has a greater than average significance in gauging their abilities. Since their structure of abilities consists of pinnacles and pits, an averaged mean might easily indicate a flat plain. 
Individuals with a dual speciality can easily fall into the vicious circle of underachievement owing to their failures. When they do, their self-esteem is low, they tend to avoid making an effort and appear unmotivated. Consequently, regular motivation assessments do not necessary reflect their true internal drive.

It is particularly true in the case of individuals with a dual speciality that the best way of gifted identification is observation during gifted education. Individuals with a dual speciality should be offered the most appropriate developing environment for their characteristics like everyone else. If they receive this, then the environment should set up suitable expectations and need not hand out waivers. Achievements are rooted in coping and taking on challenges rather than avoiding making an effort.

Finding the appropriate vocation and building up a career is an important form of gifted education assisting integration. This type of talent fits less into its environment owing to its dual speciality, while effective use of its achievements requires finding the right place and vocation for creative work. The mentor system has an especially significant role in the provision of individuals with a dual speciality. The support from the mentor is not only important with regard to talent, but also aids integration.

There is a greater need for teamwork than average in the case of individuals with a dual speciality. In most cases, more professionals than is regular are involved.

\section{The provision of the most involved groups of talents with special education needs or integration and learning difficulties}

\section{a) Socio-culturally disadvantaged talents}

In absence of efficient interaction, socio-cultural disadvantage increases with age. Gifted education should begin at an early age to ensure that socialization is suitable for gifted development. In the case of socio-culturally disadvantaged individuals, the family is usually unable to provide a suitably developmental background even despite their efforts and constructiveness. It is important to monitor the social and personal factors and offer appropriate information to talented children of socio-culturally disadvantaged families on their life opportunities. It is also immensely difficult for socio-culturally disadvantaged talents to make up for the cultural difference between their own and even the average cultural background. In programmes for these individuals, significant emphasis should be laid development of cultural and ethical sense. This is particularly effective in the area of free-time activities.

Socio-culturally disadvantaged individuals also suffer disadvantage in the educational system, as well, since school builds on verbal-analytical-logical thinking, while these individuals tend to be more efficient in holistic-visual-kinaesthetic information processing. Everyone would benefit from an education that allowed for different modalities and cognitive functioning in the processing of the learning material.

\section{b) Neurologically based achievement and behaviour disorders and conduct disorder}

Today's school builds unilaterally on left hemisphere verbal-analytical thinking, while right hemisphere holistic-visual-kinaesthetic approach is reduced to the background. Outstanding cognitive achievements and talent, on the other hand, requires the functioning 
of the whole brain. The unilateral nature of school has a significant role in the development of neurologically based achievement disorders and it also has an adverse effect on the development of talents.

The neurological type often manifest as neurologically based achievement disorders is over-represented in the outstandingly creative talent population. Increased stimulus hunger, strong energetic background and lesser obstacles to the internal drive results at higher ability levels in a set of features characteristic of outstanding talent.

Conduct disorder is not rooted in a congenital or early brain trauma, but is a reaction to regular and persistent negative environmental effects. Provision appropriate for the abilities of individuals with special education needs or integration and learning difficulties plays an important role in the prevention of conduct disorder. Underachievement and antisocial personality development invariably arises through the incongruence of the individual and the environment.

\section{c) Talents with sensory or motor disabilities}

Since the deficits are conspicuous in the case of this group, the attention of the environment is focused thereon, and thus while provision for the disability is ensured, gifted support is not necessarily aided and catered for. Deficits often beget extra (compensational) abilities, which may form the basis of outstanding achievements. The giftedness of disabled individuals may manifest itself in areas unrelated to the disability (1), in areas of outstanding achievements despite their disability (2), or, finally, in areas beyond the majority of society (3), being an extra ability developed because of the disability.

\section{d) Autistic developmental disorders and giftedness}

Groups of autistic individuals is a highly involved population with respect to talent. The integration of autistic talents can depend in many respects on the approach of the environment, as well as on human and material resources. Understanding and accepting an autistic individual's way of thinking can improve the quality of social relations irrespective of the level of the individual's abilities. In the case of autistic individuals with outstanding abilities this approach is indispensable with regard to the development of talent.

\section{e) The question of mental retardation}

Whether autistic or not, any mentally retarded individual may possess outstanding abilities. An extreme manifestation of this is the savant syndrome, which is an outstanding ability in some highly specific area paired with mental retardation or autism. A savant is not a talent, because a savant reproduces and copies rather than creates. Savants miss the high level of creativity in their activities, which are nonetheless desirable activities, because they bring joy to the individual and bring about an achievement.

Groups of individuals labelled mentally retarded and of individuals who are actually mentally retarded, however, do not exactly coincide. It is not uncommon that talented individuals are diagnosed as mentally retarded, for instance because of socio-cultural disadvantages and/or their way of thinking that is significantly different from regular. 
It is especially frequent for individuals with a dual speciality to achieve very poorly in ability assessments, while their abilities are outstanding. In light of all this, the presence of gifted education in institutions working with mentally retarded individuals is of profound significance.

It is highly important to secure the diversity of gifted education programmes both in research and in practice, and the official recognition of this approach is indispensable. The digital age presents new challenges for gifted education, as well, and a background approach is necessary which is of use in different socio-cultural environments.

\section{References}

Balogh L., \& Mező F. (Eds.). (2010). Fogalomtár a tehetségpontok számára. [A glossary for talent points]. Magyar Géniusz Integrált Tehetségsegítő Program [Hungarian Genius Integrated Talent Support Programme].

Csapó M., Gajić O, \& Ivanović, J. (2011). A tehetséggondozás mai nézetei. [Current approaches in gifted education] In. szerk. Takács M, Bene A.: A tehetséges tanulókkal való munka módszertana. V. Nemzetközi tudományos konferenciájának elöadásai [Lectures from the 5th international conference on the methodology of working with gifted learners]. University Novi Sad Faculty Magyar Tannyelvü Tanítóképző Kar, Subotica, Serbia.

Csermely P., Kovács I., Mihalik A., Nanasi T., Rak A., \& Szalay M. (2009). Hogyan küzdik le a válságokat a biológiai hálózatok, és mit tanulhatunk el tőlük? [How do biological networks overcome crises and what can we learn from them?]. Magyar Tudomány, 170: 1381-1390

Csermely, P. (2008). Creative elements: network-based predictions of active centres in proteins, cellular and social networks. Trends in Biochemical Sciences, 33, 569-576.

Czeizel E. (1997). Sors és tehetség. [Fate and talent]. FITT Image and Minerva, Budapest.

Dabrowski, K., \& Piechowski, M. M. (1977). Theory of levels of emotional development. Oceanside, NY: Dabor Science.

Dóczy J. (1910). Tehetség és iskola. A szellemi tehetség fokának és irányának figyelembevétele az oktatásban. [Talent and school. Taking the degree and direction of cognitive talent into consideration in education]. Nagel, Budapest. 153 p.

Fehérvári A., \& Liskó I. (2006). A follow-up study to the Arany János Program. Budapest: Higher Education Research Institute.

Gagné, F. (1991). Toward a Differentiated Model of Giftedness and Talent. In Colangelo \& Davis (Eds.): Handbook of Gifted Education. Boston: Allyn \& Bacon. 65-80.

Gyarmathy É. (2002). A hiperaktivitás kezelése. [Treating hyperactivity]. Új Pedagógiai Szemle, Vol 52, Nov. 84-89.

Gyarmathy É. (2007). A tehetség - Háttere és gondozásának gyakorlata. [Giftedness - its background and its support in practice]. ELTE Publishing, Budapest.

Gyarmathy É. (2010). Hátrányban az elöny. A szociokulturálisan hátrányos tehetségesek. [Advantage in disadvantage. Socio-culturally disadvantaged talents]. Budapest: Géniusz Project. 
Gyarmathy É. (2011). Kreativitás és beilleszkedési zavarok. [Creativity and integration disorders] In. (Ed.) Münnich Ákos: A kreativitás többszempontú vizsgálata. [A multi-view study of creativity]. Debrecen University, Didakt Publishing, Debrecen. 13-45.

Gyarmathy É. (2012). Digitális kor és a tanulási zavarok. [The digital age and learning difficulties]. Múszaki Könyvkiadó, Budapest.

Gyarmathy É. (2012a). Szakmai alapok a nemzeti tehetséggondozás továbbfejlesztéséhez. [Professional foundations for an improvement of national gifted education] In Ed. H. Nagy A. Szakmai ajánlások a nemzeti tehetséggondozás továbbfejlesztéséhez. [Professional suggestions for an improvement of national gifted education]. Hungarian Géniusz Programme, pp 6-10.

Gyarmathy É. (2012b). Egyenlő hozzáférés biztosítása az SNI-s, BTM-es, és alulteljesítő fiatalok esetében. [Securing equal access for youths with SEN, or integration, learning and conduct disorders, and underachieving youths]. In Ed. H. Nagy A.: Szakmai ajánlások a nemzeti tehetséggondozás továbbfejlesztéséhez. [Professional suggestions for an improvement of national gifted education]. Hungarian Géniusz Programme, pp 21-24.

Gyarmathy É. (2012c). Sajátos nevelési igényű valamint a beilleszkedési és tanulási zavarokkal küzdő tehetségek legföbb érintett csoportjai. [The most involved groups of talents with special education needs or integration and learning difficulties] In Ed. H. Nagy A. Szakmai ajánlások a nemzeti tehetséggondozás továbbfejlesztéséhez. [Professional suggestions for an improvement of national gifted education]. Hungarian Géniusz Programme, pp 25-29.

Győri F. (2011). A tehetségtérképektől a tehetségföldrajzig. [From talent maps to talent geography.] Tér és Társadalom Vol. 25, No. 4.

Harsányi I. (1994). Tehetségvédelem. [Talent protection]. Magyar Tehetséggondozó Társaság [Hungarian Society for Gifted Support], Budapest.

Hatvani A. (2011). In Estefánné Varga M. (Ed.), Megújuló tananyagtartalmak, módszerek a kompetenciaalapú tanárképzésben. Eger: Eszterházy Károly Főiskola.

Kopp M., \& Skrabski Á. (2009). Nők és férfiak egészségi állapota Magyarországon [The status of health in women and men in Hungary], In (eds) Nagy lldikó - Pongrácz Tiborné: Szerepváltozások. Jelentés a nők és férfiak helyzetéröl. [Role changes. A report on the situation of women and men]. TÁRKI - Ministry of Social Affairs and Labour. Budapest. 117-136. p.

Nagy E. (2011). Korai tehetségazonosítás és tehetséggondozás. [Early gifted identification and gifted education]. M.A. Thesis. Pedagogical Faculty of Szent István University, Szarvas

Nagy L. (1930). A tehetség lélektani problémái. [Psychological problems of giftedness]. A Gyermek. 8-15. p.

Public education act (2012) Available at http://www.kormany.hu/hu/nemzeti-eroforrasminiszterium/oktatasert-felelos-allamtitkarsag/hirek/a-nemzeti-koznevelesrol-szolotorveny-koncepciojaPappné Gyulai K., \& Pakurár Miklósné. (Eds.) (2011). A debreceni példa. Tehetségazonositás és tehetséggondozás a város közoktatási intézményeiben. [The 
Debrecen example. Gifted identification and gifted education in the city's public education institutions]. Budapest: Géniusz Project.

Pléh, Cs. (2010). Kreativitás, tehetség és gyakorlás: hangsúlyváltások a kutatásban. [Creativity, giftedness and practice: change of emphases in research]. Magyar Pszichológiai Szemle, 65. 2. 199-220.

Polgár L. (2008). Nevelhetsz zsenit.... [You can raise a genius...] Kossuth Kiadó, Budapest Renzulli, J. (1978). What makes giftedness? Reexamining a definition. Phi Delta Kappa, 60, 180-184, 261.

Révész G. (1918). A tehetség korai felismerése. [Early identification of giftedness]. Budapest: Benkő Gyula Csász és Kir. Könyvkiadó.

Simonton, D. K. (1994). Greatness: Who makes history and why. New York: Guilford Press.

Simonton, D. K. (2004). Creativity in science: Chance, logic, genius, and Zeitgeist. Cambridge University Press, Cambridge, UK

Sternberg, R. J. (1993). Procedures for identifying intellectual potential in gifted: A perspective on alternative "Metaphors of Mind". In Heller, Mönks \& Passow (Eds.): International Handbook of Research and Development of Giftedness and Talent. Oxford: Pergamon. 185-208.

Szitnyai E. (1904). A szellemi tehetségek eredete. [The origin of cognitive talents]. A Magyar Filozófiai Társaság Közleményei 13-14.

Vass V., Dobó I., Nahalka I., Ollé J., Perjés I., \& Virányi A. (2011). Tehetségkutatás a gyakorlatban. A tehetséggondozás hazai és nemzetközi komparatisztikai kutatása. [Gifted research in practice. A comparative study on national and international gifted education] Budapest: ELTE, Faculty of Pedagogy and Psychology. 